\title{
Partituras de temporalidades inconciliáveis
}

\author{
Isabel Carneiro \\ Universidade do Estado do Rio de Janeiro
}

\begin{abstract}
Resumo
Este trabalho investiga produções artísticas que relacionem música e pintura, a noção de fragmento e diário a partir da forma-partitura. A questão da forma-partitura aparece como conceito que possibilita a relação entre música e pintura, pois oferece uma forma de anteparo entre visualidades e sonoridades. Nesta noção de formapartitura, tenta-se estabelecer a ideia de deriva situacionista com a proposta de Guy Debord de desarticular o fluxo contínuo da cidade, assim como elaborar uma nova cartografia utilizando os territórios físicos, fazendo analogia com os compassos musicais. Cada território traçado pelo mapa Naked City é constituído da sobreposição de várias camadas sonoras de 1957 a 2014. A partir do mapa, a autora estabelece novas derivas em 2014 e amplia a noção de mapa, entendendo-o como uma partitura no sentido expandido. A ideia da cartografia é a apreensão musical da cidade: mapear, criar territórios onde a sonoridade possa existir.
\end{abstract}

Palavras-chave: Artes visuais. Fragmento. Sonoridade. Visualidade. Partitura.

Um suicídio calculado com grande antecedência, pensei, e não um ato espontâneo de desespero.

Thomas Bernhard

\section{Náufrago}

\begin{abstract}
Porque não atingimos o máximo, não o ultrapassamos, pensei; porque, diante de um gênio no nosso campo de estudos, desistimos. Mas para ser sincero, eu nunca poderia ter sido um virtuose do piano, porque no fundo jamais quis ser um, e sempre tive as maiores restrições a isso, tendo sempre e somente vilipendiado o virtuosismo em meu processo de definhamento, sempre achando o pianista um sujeito ridículo, desde o começo; seduzido por meu talento absolutamente extraordinário ao piano, eu me meti a ser pianista e, de repente, depois de uma década e meia de tortura, reneguei esse mesmo talento, sem qualquer escrúpulo. (BERNHARD, 2016, p. 16).
\end{abstract}

O Náufrago, livro de Thomas Bernhard, é uma narração convulsiva sobre três talentosos estudantes de piano que se encontram num curso do Mozarteum de Salzburg durante o pósSegunda Guerra Mundial. Um deles é o canadense Glenn Gould, que será consagrado em seguida como um dos maiores gênios do piano do século XX por sua interpretação das Variações Goldberg, de Bach. E será justamente ao ouvir essa interpretação pela primeira vez, em 1953, que os outros dois colegas - mas sobretudo Wertheimer, o "náufrago" do título - terão suas vidas aniquiladas. Empenhado ao máximo em seu radicalismo pianístico, ao ouvir a execução das Variações Goldberg por Glenn Gould, Wertheimer teve a semente do 
suicídio plantada em sua alma. Acreditando que o colega seria o maior intérprete de todos os tempos e na impossibilidade de ser melhor virtuose do que ele, desiste da música e da vida.

Paul Cézanne, durante toda a vida e ainda ao final dela, se questionava se sua obra não seria fruto de um distúrbio, de um defeito físico da visão. Segundo Merleau-Ponty, o pintor "indaga se a novidade de sua pintura não provinha de um distúrbio visual, se toda a sua vida não se fundamentou em um acidente do corpo" (MERLEAU-PONTY, 2004, p. 113). Cézanne dá continuidade às obras dos grandes mestres, como Tintoretto e Delacroix, e se coloca como pintor no curso da história: "Eles faziam quadros e nós tentamos um pedaço da natureza" (idem).

Para falar a respeito da impossibilidade das partituras de temporalidades inconciliáveis seria necessário buscar estas duas figuras - Wertheimer e Cézanne -, que funcionariam como "personagens conceituais", conceito deleuziano ${ }^{1}$ cujo papel principal seria o de manifestar os territórios, desterritorializar e reterritorializar o pensamento ou o conceito. $O$ personagem conceitual é o intermediário entre o conceito e o pré-conceitual, pois ele detém os pressupostos subjetivos e traça o plano do conceito. "Por exemplo, se dizemos que um personagem conceitual gagueja, não é mais um tipo que gagueja numa língua, mas um pensador que faz gaguejar toda a linguagem" (DELEUZE, 1992, p. 32).

Wertheimer e Cézanne alteram a concepção de arte, modificam a noção de história e "fazem gaguejar toda linguagem", pois rompem com o desenvolvimento da pintura e da música. Wertheimer e Cézanne, personagens do campo da música e do campo da pintura, respectivamente, um ficcional e o outro histórico, empenham-se em destruir a grande pintura e a grande música acreditando em seus paradigmas, pois fazem isso mediante um gesto iconoclasta.

Em Cézanne, a observação da pintura é impregnada por uma nova concepção do olhar. Ele inventa a capacidade de olhar para a coisa em si. A ideia de capturar um instante inteiro é tão radical porque pressupõe destruição e recombinação dos elementos pictóricos. Cézanne inventa a "perspectiva vivida", que não é a perspectiva geométrica ou fotográfica; é um olhar a partir da cisão entre o que ele vê e o que pinta. Sua pintura sofre de duplo fracasso, sua vontade de destruir a grande pintura é ao mesmo tempo a de pertencer ao fluxo da história. Sua pintura é abertura e gesto iconoclasta. Segundo Merleau-Ponty, um paradoxo:

Procurar a realidade sem abandonar as sensações, sem ter outro guia senão a natureza na impressão imediata, sem delimitar os contornos, sem enquadrar a cor pelo desenho, sem compor a perspectiva ou o quadro. A isso se chama o suicídio de Cézanne: visa à realidade e se proíbe os meios de atingi-la. (MERLEAU-PONTY, 2004, p. 160).

\footnotetext{
${ }^{1}$ Gilles Deleuze e Félix Guattari, "Personagem conceitual”, em O que é a filosofia?, São Paulo: Ed. 34,
} 1992. 
Cézanne, assim como Wertheimer, procura no isolamento de sua prática artística um meio de defesa e de sobrevivência. Merleau-Ponty considera esquizoide o temperamento de Cézanne, diagnóstico que poderia ser estendido a Wertheimer. Ambos vivem ainda do paradoxo do gênio, mesmo que de um "gênio abortado" (MERLEAU-PONTY, 2004, p. 160). Wertheimer nunca chegou a se tornar um virtuose no piano, sua fragmentação ou loucura levou-o ao gesto aniquilador de querer tocar um piano velho e desafinado, que não serviria para nada, apenas para elucidar a impossibilidade de se tocar piano depois das Variações Goldberg, de Glenn Gould.

\begin{abstract}
Wertheimer telefonara para Salzburgo para encomendar o piano, e o Franz se lembrava muito bem de que, ao telefone, seu patrão tinha enfatizado diversas vezes que deveriam mandar para Traich um piano bem vagabundo e horrorosamente desafinado, teria repetido Wertheimer diversas vezes ao telefone. (BERNHARD, 2016, p. 140).
\end{abstract}

A minha loucura foi rasgar, destruir todas as partituras que encontrava pelo caminho. $O$ gesto obsessivo de um virtuosismo inalcançável me levou a fragmentar tudo, todas as partituras que não poderia nunca mais executar, na verdade, não saberia mais como executálas, pois a loucura (assim como a de Wertheimer) me levou a um destemperamento, que não conseguia mais coordenar mãos e cérebro. Tudo estava cindido.

\title{
O princípio da colagem
}

É a partir da lógica de caráter destrutivo, percebida em Cézanne e em Wertheimer, que surge o estratagema da colagem. Segundo W. Benjamin:

\footnotetext{
O caráter destrutivo só conhece um lema: criar espaço; só uma atividade: despejar. Sua necessidade de ar fresco e espaço livre é mais forte que todo ódio. [...] O caráter destrutivo não está nem um pouco interessado em ser compreendido. Considera esforços nesse sentido superficiais. Ser mal compreendido não 0 afeta. (BENJAMIN, 1997, p. 236).
}

Rompimento com a profundidade é estratégia do cubismo, que traz para a superfície planar da pintura elementos heterogêneos. Ao colar o primeiro pedaço de papel sobre a pintura, Braque esclarecia o pensamento da forma, construindo um novo espaço sem perspectiva. A planaridade da pintura só foi possível porque a profundidade se tornou superfície, conceitual ou pictórica, elementos dissonantes aproximaram-se e foram colocados sobre o mesmo plano.

O princípio da colagem reúne sobre um mesmo plano duas ou mais materialidades, unindo temporariamente meios heterogêneos como música e pintura. Como trabalhar dois meios que são dessemelhantes e criam intervalos entre eles? Ao reunir sobre o mesmo plano físico ou conceitual esses dois meios, deve-se continuar a distingui-los e não amalgamá-los. 
A colagem não exclui as diferenças entre eles; mantém a autonomia dos elementos reunidos; é sempre temporária, não fixa; elementos se reúnem num determinado momento e depois se descolam, passam a existir separadamente.

Colagem como confronto histórico de dissonâncias. Colagem entre materiais plásticos heterogêneos: guardanapos e tinta óleo, e colagem de dissonâncias históricas: Man Ray e gravura japonesa, reunidos sobre um mesmo plano temporal e pictórico. Es muss sein, de Beethoven, colada com a partitura de Because, de John Lennon. O gesto de reunir fragmentos historicamente conflituosos sobre um único plano tem tradição moderna e é um impulso de ruptura. O princípio da colagem: manter temporariamente fragmentos de ordem inconciliáveis sobre um mesmo plano.

O primado do fragmentário sobre o sistemático, a constante retomada dos mesmos temas, a passagem brusca de um tópico para outro, sem transição. Benjamin quer ser lido como um mosaico, mas até que ponto esse mosaico tem de ser construído pelo leitor? Nem sempre as peças estão ordenadas. Cabe ao leitor separar e juntar os fragmentos. Um conjunto de citações. Elas têm função precisa: são estilhaços de ideias, arrancados de seu contexto original e que precisam renascer em novo universo relacional, contribuindo para a formação de um novo todo.

No conceito de história de Benjamin, o historiador dialético libera a história do fluxo contínuo, salvando sob a forma de um objeto-mônada o fragmento da história. O conceito de mônada é a melhor expressão que Benjamin atribui ao fragmento: "um salto de tigre em direção ao passado sob o livre céu da história" (BENJAMIN, 1997). O historiador faz a história por saltos, os fragmentos continuam carregando consigo sua temporalidade própria como uma "mônada" que indistintamente carrega em si todas as demais temporalidades da pré e da pós-história.

A concepção clássica do presente é a de um ponto infinitamente pequeno que divide passado e futuro. O agora de Benjamin, ao contrário, é o lugar e a ocasião em que passado e futuro visam um ao outro, onde eles se tocam... O historicismo colocava a história a serviço da salvação da memória. A causa da memória legitimava e justificava a história burguesa. Em Walter Benjamin, as posições se invertem. É a história que está perdida - definitivamente perdida para nós - sem o concurso da memória. Porém, uma vez redimida pela memória, que forma pode essa história assumir? A forma das "imagens dialéticas", dirá Benjamin. A forma dos acontecimentos poeticamente transfigurados pela memória, apreendidos, como imagem, no instante em que são "reconhecidos", isto é, no agora que este reconhecimento inaugura. As imagens da história que Benjamin nos oferece não resultam da descoberta ou da rememoração, mas deste reencontro. (LISSOVSKY, 2005, p. 34).

A colagem pressupõe a distinção entre os elementos autônomos no mesmo plano e reserva seu grau de subversão, pois trabalha com o conceito de sobreposição abrupta e heterogeneidade de meios. 


\section{Partituras de temporalidades inconciliáveis}

Partituras de temporalidades inconciliáveis é simultaneamente obra e tese. Traz a cisão e recombinação de fragmentos, pedaços de música recortados e colados aleatoriamente, ressaltando a impossibilidade de se fazer música, sempre a impossibilidade de execução, assim como a impossibilidade de se fazer pintura. É preciso cindir, romper, destruir para ainda conseguir tocar piano, para conseguir fazer pintura. Neste momento, o próprio texto funciona como partitura, daí a ideia de recortar e colar, editar o texto, escrevê-lo na forma do fragmento, uma forma de escrita que é ao mesmo tempo um procedimento de trabalho. Não tem introdução e nem conclusão. Notas como pequenas vozes reverberando no trabalho plástico que trazem para a superfície suas referências teóricas, pois elas não existem na profundidade.

Como executar uma partitura na forma de pintura e como transpor pictoricamente um som? O anteparo conquistado pela partitura traz para o mesmo plano o visual e o sonoro e é uma tentativa de correspondência entre as duas linguagens. O que na pesquisa interessa entre música e pintura é a construção de partituras que evidenciem o intervalo e a sobreposição abrupta entre uma coisa e outra, a interseção. Ao tentar elaborar anteparos entre as dimensões sonora e musical, as partituras de temporalidades inconciliáveis tentam trazer para o mesmo plano essas duas dimensões separadas historicamente, temporalidades inconciliáveis da pintura e da música.

\section{Anteparo}

Ao relacionar música e pintura como áreas fundamentais de minha prática artística, o problema central do trabalho seria investigar trabalhos artísticos que abordam essa relação, problematizando a constituição de um anteparo (partitura) entre as duas linguagens.

Deve-se levar em conta a impossibilidade de se criar um anteparo entre duas linguagens que não compartilham o mesmo campo semântico. Sabemos que a partitura não é a imagem do som e sim uma possibilidade de encontrar um código imagético para o som, assim como pode ser uma imagem, o meio físico em que a dimensão sonora é traduzida. O conceito de partitura seria o anteparo, a dimensão semântica, da notação gráfica, da escrita, do conceito, enfim, a codificação necessária entre as duas linguagens.

A ideia de partitura como anteparo deriva do conceito lacaniano de real. Segundo Lacan, real é tudo aquilo que não pode ser simbolizado e assimilável, o real é diferente do simbólico e do imaginário, o real é tudo aquilo que nos escapa. Lacan afirma que o real é sem fissura e só se o apreende por meio de um anteparo. Por isso ainda precisamos do simulacro ou do anteparo, que é a forma possível de tradução do real; a fala e o discurso preexistentes são formas de anteparo ou simulacro desse real, que é feito de cortes e impossível de ser vivenciado. No caso, a imaterialidade dessa relação entre imagem e som exige um corpo 
físico ou conceitual que chamamos aqui de partitura ou anteparo, a dimensão discursiva entre as duas linguagens.

Mais amplo do que a relação entre música e pintura é o conjunto de possibilidades resultantes dos atos de ver e ouvir, que incluem a leitura do mundo como música, as sonoridades como vozes que historicamente se sobrepõem num mesmo objeto artístico, as camadas discursivas enunciadas a seu respeito. A relação som/imagem (audiovisual) é classificação derivada de novas tecnologias como o cinema e o vídeo. Usamos esse termo em alguns momentos quando também o usam os teóricos que nos motivaram, como Michel Chion, Vânia Dantas Leite e Rodolfo Caesar. A designação que mais utilizaremos, entretanto, também foco de nosso interesse, é a música e a pintura como uma das possibilidades da relação som/imagem. A pesquisa surge, portanto, da problematização do conceito de partitura, compreendida nos dois sentidos: transformar música em pintura e pintura em música. A relação música/pintura é um caso particular da relação entre som e imagem.

A partitura convencional se constrói a partir do pentagrama de coordenadas cartesianas - tempo e espaço. A tentativa de construir escritas a partir de sonoridades, porém, considera que o conceito amplo de partitura pode ter como objeto uma pintura, uma dança, uma imagem, uma arquitetura ou um vídeo. Essa problematização se dá em vários trabalhos artísticos na transição do moderno para o contemporâneo, quando a partitura do pentagrama não consegue mais codificar as múltiplas situações sonoras. Além de ser "escrita do som", a partitura passou a ser também a "escrita de uma imagem".

\section{Mapa}

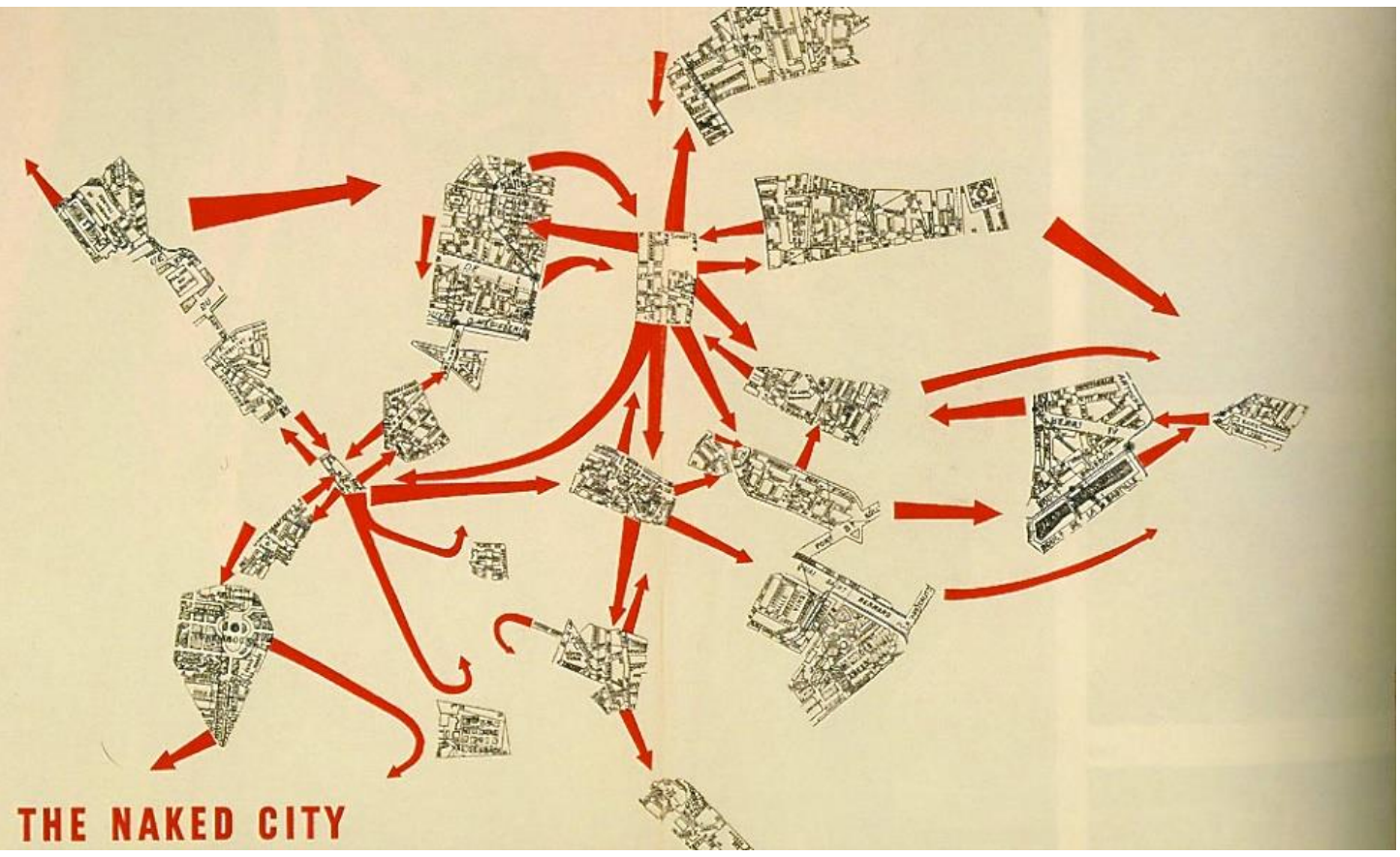

Guy Debord, Naked City, 1957 (print screen) 
Inicio o trabalho com a performance Naked City, um programa de derivas pela cidade de Paris a partir da obra de Debord, de 1957.

Naked City ${ }^{2}$ é a melhor maneira de exemplificar questões como a partitura como anteparo, o sistema diário, a ideia do fragmento, a invenção de signos arbitrários, cisão, recombinação, programa e registro. O trabalho constrói novas derivas em Paris a partir do mapa Naked City, compreendido como partitura em sentido expandido. $O$ ato de caminhar e perceber as sonoridades da cidade é um dos aspectos da obra. Essas derivas, registradas em vídeo, áudio e em curtos textos, trazem a escrita automática como situação integrante do trabalho.

Quando designo partitura, essa noção está além da codificação musical do senso estrito, configurando-se, por exemplo, nas notações gráficas de Anestis Logothetis, que são partituras-desenhos; em Naked City, de Debord, que é um mapa cartográfico de derivas por Paris; ou no caso de 0'00", de Cage, em que a própria obra é a construção de uma partitura. Para John Cage, a realização da obra 0'00" (4'33" No. 2) era questão de construir uma partitura tão aberta quanto possível eliminando o intervalo entre leitura e execução; assim, a própria obra deve ser entendida como uma partitura expandida capaz de não omitir qualquer movimento, situação, interpretação ou som.

Quando somos convocados por Cage para abrir nossos ouvidos para a 5 avenida, em Manhattan, o entendimento de uma paisagem sonora está implícito. Quais são os mapaspartituras que podemos construir com os sons não intencionais?

Os lugares representados pelo mapa psicogeográfico Naked City (1957) de Guy Debord são: canal St. Martin, Boulevard de la Chapelle, rue d'Aubervilliers, canal de l'Ourqc, Jardin du Luxembourg, l'axe entre le Palais Royal au Nord et la Place de I'Institut au sud, palais du Louvre, le quartier de l'Eglise Saint-Merri, la rue de Seine, le boulevard Saint-Germain, rue Mazarine e rue de Poissonniers.

Propor novos jogos para percorrer esses lugares e depois confeccionar uma partitura com as sonoridades dos territórios-compassos. Cada território-compasso foi impresso através do Google Earth; a partir dessa localização estabelecemos jogos transformados em partituras: 1 min de filmagem e 1 min de captação sonora. Ao final da deriva me sentava num café mais próximo e escrevia as primeiras coisas que me vinham à mente, numa tentativa de escrita automática remetendo à escrita surrealista de Breton. Cada território-compasso foi enviado pelo correio mais próximo para algum amigo com a imagem do Google Earth do local.

\footnotetext{
2 A segunda parte do trabalho intitulado Naked City foi publicada nos anais do Encontro Nacional da ANPAP em 2015. Esta é uma versão revista e atualizada. Ver: CARNEIRO, 2015.
} 


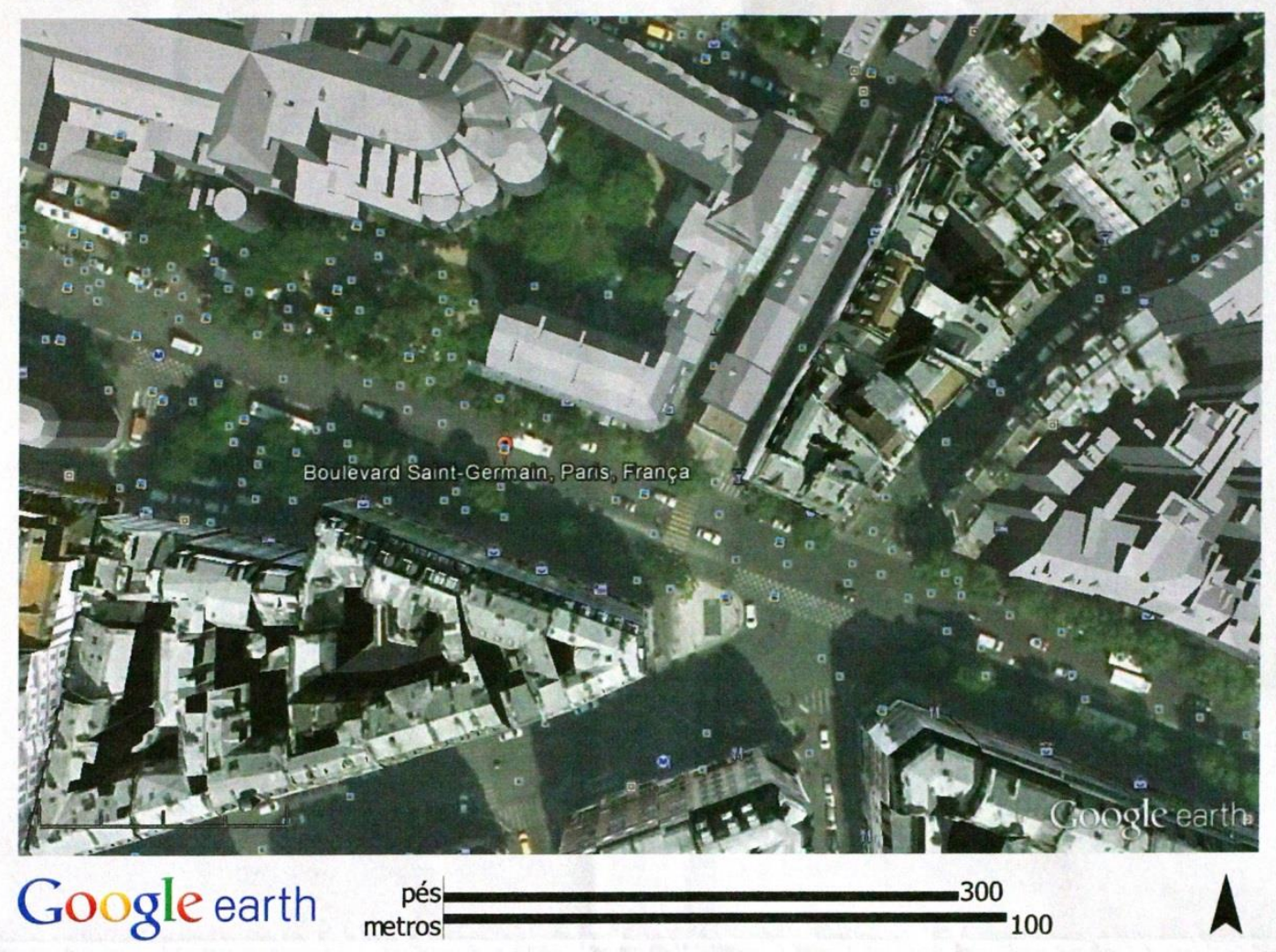

le boulevard Saint-Germain

Raquel Versieux

Praces Pic $\overline{X I}$, to/303. Jardim Batanico. Rio $\alpha$ Jaruive-RJ.

Cep: 22.961-080

Isabel Carneiro, performance Naked City, 2014

Escrita automática das apreensões afetivas dos territórios-compassos. A lista que fiz dos lugares parte de uma enumeração disjuntiva, exprime uma fragmentação, uma esquizofrenia do sujeito - conceito importante ao acionar um estado esquizofrênico e traçar derivas no espaço compartimentado da cidade. O sujeito que percebe uma sequência de impressões disparatadas sem conferir nenhuma unidade a elas, faz emergir narrativas pessoais e coletivas no processo de construção de subjetividades.

Me propus a fazer uma cartografia sentimental: me apropriei do conceito de "corpo vibrátil" de Suely Rolnik para construir processos de subjetividade que atravessam o espaço comum urbano e o próprio corpo e assim constituem novas maneiras de deambulação objetiva e subjetiva pela cidade. 
Entre a vibratibilidade do corpo e sua capacidade de percepção há uma relação paradoxal. É a tensão desse paradoxo que mobiliza e impulsiona a potência da criação, na medida que nos coloca em crise e nos impõe a necessidade de criarmos formas de expressão para as sensações intransmissíveis por meio de representações de que dispomos. Assim, movidos por esse paradoxo, somos continuamente forçados a pensar/agir de modo a transformar a paisagem subjetiva e objetiva. (ROLNIK, 2011, p. 13).

Podemos aderir à figura do cartógrafo como artista. Que cria regras próprias para investigar o finito ilimitado do processo de produção de realidade que é desejo, pois é através do desejo que poderiam se formar as possíveis estratégias do "corpo vibrátil" nas cidades. A função do cartógrafo-artista segundo Rolnik seria:

[...] o que importa é que o cartógrafo esteja atento às estratégias do desejo em qualquer fenômeno da existência humana que se propõe a perscrutar, desde os movimentos sociais, formalizados ou não, as mutações da sensibilidade coletiva, a violência, a delinquência... Até os fantasmas inconscientes e os quadros clínicos de indivíduos, grupos e massas, institucionalizados ou não. (ROLNIK, 2011, p. 14).

Percorrer os mesmos territórios contidos no mapa de 1957 possibilitava uma nova forma de fazer derivas. Elaborei o programa da deriva de 2014 a partir dos textos de Debord: fazer as deambulações entre um sono e outro caminhando a pé, o mais rápido possível, apenas 1 min. Ao invés de traçar as minhas próprias derivas e construir um material que podia se assimilar com caminhadas despropositadas pela cidade, fazendo emergir o caráter turístico do passeio pelas ruas de Paris, decidi construir derivas a partir de Debord. Com isso criava um diálogo vivo e a tentativa de um encontro mais profundo com o fazer repetitivo e diário. Tornou-se mais importante reconstruir e diferenciar. Colocar em relação as derivas de 1957 e de 2014 significa promover uma continuidade e descontinuidade, estabelecer o antes e o depois, observar o presente e o passado. Ver e sentir como a cidade se organizou, perceber as padronizações da deambulação promovidas em uma cidade que se compartimenta e exerce uma função de regramento e de divisão entre diversas camadas sociais. Como as derivas de Debord compreendem vários territórios que fogem da centralidade turística de Paris, pude perceber nessa caminhada hodológica as diversas maneiras e comportamentos na construção de uma subjetivação dos lugares, formas de contenção e agrupamento entre as diferentes áreas.

Gilles Tiberghien, em seu texto Hodológico, investiga produções artísticas que tem o ato de caminhar como matéria plástica. O termo hodológico provém do grego hodos, que significa rota ou viagem. A hodologia é a ciência ou o estudo das rotas. Tiberguien vai diferenciar rota de caminho, privilegiando este último: "um indivíduo pode sempre traçar um caminho em uma extensão deserta: se ele não é seguido por seus semelhantes, seu caminho mão irá se tornar jamais uma rota ou uma rua" (TIBERGHIEN, 2012, p. 168). O caminho é sempre afetivo, "um caminho objetivamente mais longo pode ser mais curto do que um caminho objetivamente 
mais curto, se este último é um verdadeiro calvário e se parece àquele que o percorre infinitamente longo" (idem). Assim, um caminho pode ser privilegiado pela familiaridade ligada ao fato de que o tomamos apenas na companhia da mesma pessoa. Nesse caso, o mínimo de dispêndio afetivo pode se traduzir por um máximo de dispêndio físico. Podemos dizer que o caminho familiar se apresenta como um filete fluído no interior de uma massa viscosa. Talvez esteja aí uma expressão que possamos utilizar para caracterizar nossos deslocamentos quotidianos nas grandes metrópoles. "Não caminhamos em um lugar, mas em um espaço, porque caminhar é carecer de lugar. É o processo indefinido de estar ausente e em busca de um lugar próprio" (idem, p. 170). Segundo Tiberghien, o interesse pelos mapas na contemporaneidade é devido a sua natureza complexa: não estão inteiramente ao lado das imagens nem inteiramente ao lado dos conceitos, que são, se preferirmos, espécies peculiares de imagens que procedem a um só tempo da representação concreta e do pensamento abstrato. As analogias entre mapas e partituras são muitas na contemporaneidade, as partituras trabalham com a ideia de uma imagem codificada, uma forma visual que será transformada em música, como os doze pontos da Naked City de Debord: "Escreve para descrever (literatura) ou permite fazer notações (música)" (TIBERGUIEN, 2013, p. 20).

Percorrer os mesmos territórios e construir novas partituras cartográficas. Quais são os sons delas hoje? Qual será minha relação com as antigas sonoridades de Debord? Quais seriam as camadas discursivas e sonoras dessa performance? Como o tempo se cristalizaria nessas situações? Criar outras derivas a partir desses lugares, transformando-as em partituras entendidas como cristalizações dessas deambulações. A partitura é o registro dessas ações, o anteparo entre o som e a imagem. Como Naked City, um registro, uma construção gráfica do percurso das derivas.

\section{Partitura da deriva}

Situacionismo é um modo de operar artisticamente dentro do cotidiano. Situacionista é o que se refere à teoria ou à atividade prática de construção de situações; indivíduo que se dedica a construir situações.

\footnotetext{
Nossa ideia central é a construção de situações, isto é, a construção concreta de ambiências momentâneas da vida, e sua transformação em uma qualidade passional (superior). Devemos elaborar uma intervenção ordenada sobre os fatores complexos dos dois grandes componentes que interagem continuamente: o cenário material da vida, e os comportamentos que ele provoca e que o alteram. (DEBORD apud JACQUES, 2003, p. 21).
}

Segundo o glossário da Internacional Situacionista de 1958, deriva é o comportamento experimental ligado às condições da sociedade urbana; técnica da passagem brusca através 
de ambientes variados. Emprega-se também, mais particularmente, para designar a duração de um exercício contínuo desta experiência. A ideia de deriva situacionista é um jogo construído para desarticular o fluxo da cidade e criar novas formas de caminhadas sem formas pré-concebidas.

A deriva situacionista começa com a impregnação de eventos não determinados no dia a dia da cidade. A deriva seria uma apropriação do espaço urbano pelo pedestre através da ação do andar sem rumo. Através das derivas, a psicogeografia estudava o ambiente urbano, sobretudo os espaços públicos, e tentava mapear os diversos comportamentos afetivos diante dessa ação básica do caminhar na cidade.

O deserto é monoteísta, já disseram há muito tempo. Parecerá ilógica, ou desprovida de interesse, a constatação de que o bairro parisiense que vai da praça Constrescarpe a rue de Arbalete exerce uma influência no sentido do ateísmo, do esquecimento, e da desorientação dos reflexos habituais? (DEBORD, 2000, p. 47).

Psicogeográfico é o que manifesta a ação direta do meio geográfico sobre a afetividade. O procedimento psicográfico de Guy Debord estudava os efeitos do ambiente geográfico, conscientemente organizado ou não, nas emoções, maneiras, comportamentos, modos de ação, procedimentos e condutas e atos de um indivíduo. A psicogeografia seria então uma geografia afetiva, subjetiva, que buscava cartografar as diferentes ambiências psíquicas provocadas basicamente pelas deambulações urbanas.

A duração média de uma deriva é a jornada, considerada como o intervalo de tempo compreendido entre dois períodos de sono. Os pontos de partida e de chegada, no tempo, em relação ao dia solar, são indiferentes, mas convém lembrar que as horas da madrugada são geralmente impróprias à deriva...Mas a deriva costuma desenrolar-se em algumas horas deliberadamente marcadas, ou até fortuitamente por breves instantes, ou ainda durante vários dias sem interrupção." (DEBORD, 2000, p. 89).

Em Naked City (1957), Debord faz uma colagem de vários pedaços do mapa de Paris de acordo com suas derivas. Essa talvez seja a melhor ilustração do pensamento urbano situacionista, a melhor representação gráfica da pscicogeografia e da deriva, e também um ícone da própria ideia de urbanismo unitário. É composta por vários recortes do mapa de Paris em preto e branco, correspondendo a unidades de ambiência, e setas vermelhas que indicam as ligações possíveis entre essas diferentes unidades. As unidades estão colocadas no mapa de forma aparentemente aleatória, pois não obedecem à sua localização no mapa da cidade real, mas demonstram uma organização afetiva desses espaços ditada pela experiência da deriva.

Naked City funciona como percurso assim como mapa. Como mapa, mostra os vários lugares da cidade de Paris e enquanto percurso, traça distâncias e sequências de como esse mapa deve ser percorrido. A distinção é feita por Michel de Certeau, para quem percurso é 
uma série discursiva de operações: "você dobra a direita e entra na sala de estar". Nele, a medida do corpo se faz necessária, diferente do mapa que é uma descrição redutora e totalizante das observações, uma abstração: "ao lado da cozinha fica o quarto das meninas" (CERTEAU, 2012, p. 186-187).

A experiencia da deriva é ligada à ideia de jogo, trata-se de desarticular o tempo e o espaço criando outras camadas de entendimento da cidade:

Já indicamos a necessidade de construir situações como um dos desejos básicos sobre os quais se há de estabelecer a próxima civilização. Essa necessidade absoluta de criação esteve ligada à necessidade de jogar com a arquitetura, o tempo e o espaço. (IVAIN apud JACQUES, 2003, p. 69).

O espaço psicogeográfico de Debord pode ser comparado a uma estrutura musical. Entendida como procedimentos de atuação, circulação e jogo para romper o fluxo habitual da cidade de Paris, Naked city seria uma partitura de ação, uma partitura performática em que espaço e tempo são assinaláveis como estruturas rítmicas e melódicas. Configura-se como tal na ação de percorrer os espaços, percebendo física e corporalmente a relação psicogeográfica estabelecida nesta colagem de territórios-compassos. É antes de tudo um procedimento performático em que cada território-compasso pode ser experimentado diferentemente do anterior e assim se tornar uma partitura tão aberta a indeterminações como as partituras de Shoënberg ou John Cage. A relação com o tempo que se desdobra é um tempo expandido, podendo ser comparado ao tempo indeterminado de cada intérprete como nas performances de Cage. A indeterminação é empregada na música como um meio de ampliar o sistema de opções que a obra oferece. Para Cage, a indeterminação como aleatoriedade acontece dentro do campo de possibilidades da obra.

\section{Caminhar, ouvir}

Caminhar se torna uma maneira privilegiada de escutar o mundo e prestar atenção porque se mover é também uma forma de se colocar à escuta. (GILLES apud DAVILA, 2002, p. 161).

O ato de caminhar abre os ouvidos. Entre 1966 e 1976, Max Neuhaus, percussionista e um dos precursores da arte sonora dos anos 1960, cria deambulações pela cidade de Nova York em operações que ele descreve assim: "A primeira dessas performances concernia de um grupo de amigos convidados. Eu marquei um encontro no início da avenida $D$ na 14 de Manhattan. Carimbei sobre a mão de cada um a palavra ESCUTA." Com isso, descobre que os ruídos podem se tornar sons. Essas caminhadas sonoras permitem prestar atenção aos ruídos que se oferecem como matéria sonora no espaço da caminhada: "começamos a descer a rua 14 , onde a rua se bifurca numa central elétrica, nós escutamos um enorme e espetacular 
rugido. Nós continuamos a descer ao longo de uma rua de casas atravessando a autopista e andando sobre uma multidão fatigante que transpirava."

Em Marcher et créer, Thierry Davila vai se referir ao conceito de sons ready-mades a partir da obra de Neuhaus. O que seriam sons ready-mades? O apito de uma fábrica é um som ready-made? Ele pode sair da esfera dos ruídos não intencionais e ser produzido de forma intencional por um instrumento como o itanumori de Russolo e ainda assim manter-se como som ready-made? Ser reconhecível é condição do som ready-made? Sons intencionais podem ser considerados sons ready-made? Para Neuhaus, o que se ouve - e não o que vemos - é o que nos localiza no espaço. Ele constrói percepções do espaço através dos sons, o que ele denominou de "instalação sonora", que não são músicas nem eventos. A instalação sonora seria o próprio evento de dispor-se a caminhar e registrar as percepções, compreendendo-as de forma musical. Brandon Labelle vai se referir à instalação sonora de Neuhaus:

Frequentemente creditado a Neuhaus, instalação sonora reúne som e espaço de uma forma provocativa e estimulante, geralmente baseando-se em elementos arquitetônicos e construção, eventos sociais, ruído ambiental e dinâmicas acústicas, dentro e fora da galeria, ao mesmo tempo recorrendo à compreensão musical. Desta forma, a instalação sonora substitui os domínios apartados da performance musical com geografias espaciais, investigações de sistemas eletrônicos (os quais Neuhaus conhecia bem) e seus ruídos subsequentes com as condições do espaço urbano e seu planejamento, situando o ouvinte em uma área geográfica mais ampla. (LABELLE apud Roça, 2013, p. 1).

\section{Escutar, ouvir}

A proposição de captar os ruídos da cidade através das derivas provém de uma ideia Fluxus, entendida como um momento em que o ordinário entrou na esfera da arte de maneira enfática, como um inventário de coisas e eventos em que não há uma distinção entre arte e não arte, assim como entre música e mero barulho ${ }^{3}$. A arte não é um recinto especial do real, e sim uma forma de experimentar qualquer coisa - a chuva, o burburinho da multidão, um espirro, o voo de uma borboleta. Esses pequenos movimentos são capturados pelos artistas Fluxus como, por exemplo, George Brecht, que inventou o que ele denominou de event-scores - partituras de ação, geralmente impressas em pequenos cartões-postais. Em suas primeiras partituras, Brecht programa ações essencialmente sonoras, como a famosa Drip Piece (19591962) que consiste em fazer escutar gota a gota o som da água caindo num recipiente. Sua proposição: "garantir que os detalhes da vida ordinária, as constelações aleatórias dos objetos que nos cercam, não possam cessar de serem marcados”. Para Brecht, retirar os objetos do

\footnotetext{
3 Optamos por escrever barulho e não ruído pela referência ao texto de Arthur Danto "O mundo como armazém: Fluxus e filosofia", em que ele faz a distinção entre música e mero barulho na obra de Cage.
} 
ordinário e colocá-los no mundo da arte como uma atitude de deslocamento duchampiano se transformou numa atitude paradoxal, pois transforma os objetos em objetos de arte e ao mesmo tempo devolve esses mesmos objetos aos seus locais de origem.

Não há diferença entre arte e vida cotidiana...eu pego uma cadeira e simplesmente a coloco numa galeria. A diferença entre uma cadeira de Duchamp e uma das minhas cadeiras é que a de Duchamp está num pedestal enquanto a minha ainda pode ser usada. (BRECHT, 2002, p. 33).

Influenciado pela obra de Cage, Brecht propõe um trabalho que transforma uma pintura branca numa partitura. A pintura branca de aproximadamente trinta centímetros foi posta para secar no exterior e com isso reteve partículas veiculadas pelo ar. Essas partículas representavam notas musicais impressas na partitura (pintura branca). "Uma vez na superfície seca, cada grão de poeira representa um som." Para Brecht, eventos sonoros, como a transformação de uma pintura branca em partitura, é uma forma de poesia que se torna ação.

Fluxus foi formado no inverno do ano 1960-1961 por George Maciunas. Maciunas promoveu pela Europa uma série de concertos Fluxus que tiveram o efeito de constituir um círculo internacional de jovens artistas. Nas próprias palavras de Maciunas, tentar definir Fluxus é desconhecer o movimento que queria prescindir de qualquer definição. Podemos perceber que Fluxus tem uma atitude antiarte, e se dá com a apreensão mínima do cotidiano. O objetivo Fluxus era a unidade entre arte e vida e assim a arte como arte seria supérflua. Para Maciunas, se o homem pudesse ter uma experiência do mundo concreto que o cerca da mesma maneira que tem a experiência da arte, não haveria necessidade de arte, nem de artistas. Fluxus era mais uma atitude mental que um movimento.

Hoje em dia quando aparece uma distração eu separo um tempinho para pensar sobre ela, ou fotografá-la, filmá-la, ou modelá-la, ou comê-la ou alguma outra coisa do estilo. Aliás, me parece que as distrações são mais interessantes do que qualquer outra coisa.-(WATTS, 2002, p. 13).

A concepção Fluxus pode ser expressa pela sua atitude contra o objeto de arte: A mesma atitude contra o objeto de arte, característica da concepção Fluxus, expressa por Robert Watts, pode ser encontrada também em George Brecht.

O que você pode realizar por meio de uma escultura não precisa ser construído como um prédio; o que pode ser feito na pintura não precisa ser cinzelado como uma escultura; o que pode ser feito por um desenho não precisa ser feito a óleo como uma pintura; o que você pode realizar por meio de um pedaço de papel não precisa ser feito a lápis como um desenho, e o que você consegue obter na sua cabeça não precisa nem de um pedaço de papel... Todo o excesso e complicadas construções além do necessário são tabu e ofuscam a simplicidade da arte. (MACIUNAS, 2002. p. 118). 
Para George Brecht, se algo fica desenvolvido, elegante ou profissional demais, então há algo de errado. "Quando o piano se transforma em tabu então ele tem de ser destruído" (BRECHT, 2002, p. 65). Negação do instrumento musical em prol de uma musicalidade a ser descoberta no mundo

As composições do artista Fluxus La Monte Young partem da construção de situações simples. Suas notações (partituras) são proposições de acontecimentos banais influenciados pelo universo do zen, como ouvir o voo de uma borboleta ou uma fogueira queimando em público. As Composition 1960 \#2 e \#5 têm por intenção fazer escutar as coisas mínimas a partir de construções sutis.

Composition \#2: Acenda uma fogueira na frente da plateia. Use madeira preferivelmente, apesar que outros combustíveis podem ser usados como for necessário para iniciar o fogo ou controlar a fumaça. A fogueira pode ser de qualquer tamanho, mas não deve ser do tipo que se associa com outro objeto como uma vela ou um isqueiro. As luzes podem ser apagadas.

Composition \#5: Solte uma borboleta (ou qualquer número de borboletas) na área de performance. Quando a composição estiver terminada, não deixe de permitir que a borboleta possa sair do auditório.

Desde 1959, o artista Fluxus Wolf Vostell escreve partituras de seus happenings ${ }^{4}$ ou o que ele chama de música de ação sob forma de notas redigidas e datilografadas. Exemplo: pegar um ônibus de linha em Paris e durante quatro horas de trajeto, não fazer nada além de escutar com atenção redobrada tudo o que possa ser ouvido. Para Wolf Vostell a situação do happening propicia uma escuta atenta a todos os barulhos que nos cercam. Vostell também trabalha com partituras rasgadas, no que ele chama de dé-coll/ages: na obra Cri existe uma página da partitura do quarteto de cordas de Mozart que é rasgada e colocada separadamente. Cada instrumentista toca somente as notas que consegue ler, formando um conjunto de sons estranhos ao ouvido.

\section{Cidade sonora, arte sonora}

O filme Weekend (1930) de Walter Ruttman tem duração de 11 min 20 s e é uma montagem de som pela película apresentando sonoramente a cidade de Berlim. É a construção da imagem através de ruídos da cidade, fragmentos, gravação de palavras, músicas, o microfone faz a captura sonora em close, sinos, voz estridente de um menino, som de tambores, serras elétricas, apito de sirene, formando uma paisagem sonora. Nos três primeiros minutos existe uma profusão de sons fortes, depois dos quatro minutos, vozes femininas silenciosas, passos na escada, um convento, o segundo movimento é mais suave.

\footnotetext{
${ }^{4} \mathrm{O}$ termo happening foi batizado pelo artista Allan Kaprow quando apresentou sua obra 18 happenings em 6 partes no outono de 1959, na Reuben Gallery, em Nova York.
} 
A partir dos seis minutos, uma música sacra com cacarejos, e mulheres rindo alto, uma banda sinfônica, último movimento colagem sonora de vozes, estação de rádio. Essas propostas evidenciam o revezamento entre som e imagem. Para Ruttman era possível construir outra cidade através dos ruídos, a relação entre música e pintura pode ser experimentado através do cinema, pois a pintura cedeu espaço para a imagem. A emergência do sonoro no filme se dá com a conjugação do visual, não se pode falar de música no cinema e sim de um acontecimento sonoro-visual. A relação embrionária do cinema, imagem e som não se dá em espaços separados, mas sim na constituição de um mesmo objeto. A ideia de Ruttman era fazer um cinema sonoro, que pudesse ser "ouvido" e não somente "visto".

\begin{abstract}
A preocupação de Ruttmann com o som no cinema revela-se objetivamente em seu texto Sound Films. Nele Ruttmann afirma que a única maneira possível de fazer um bom filme sonoro é pensar em um contraponto entre os modos de expressão visual e sonoro. E, dessa maneira, fazer um link mental" entre imagem e som, para que assim se construa um sentido. Ele dá alguns exemplos de como a montagem do audiovisual poderia ocorrer:

- Você escuta uma explosão. Você vê a cara de uma mulher horrorizada.

- Você vê uma luta de boxe. Você ouve os sons de uma multidão frenética.

- Você ouve um violino lamentoso. Você vê uma mão alisando gentilmente outra.

- Você escuta uma palavra. Você vê o efeito da palavra na cara de uma pessoa. (RODRIGUES; CHAVES, 2015).
\end{abstract}

Em 1916, Vertov criou o Laboratório de Audição, onde realizava a montagem de palavras unindo música e literatura. O artista defendia conceitos como: ruído e sons fotográficos e filme acústico. Quando preconiza um filme acústico, Vertov propõe que seria necessário fotografar os sons. A problematização da relação imagem e som nasce junto com a experiência do cinema.

E eis que, num dia de primavera, em 1918, eu volto da estação. Guardo ainda no ouvido os suspiros, o barulho do trem que se afasta...alguém que faz juras... um beijo... alguém que exclama... Risos, apito, vozes, sinos, respiração ofegante da locomotiva... Murmúrios, apelos, adeuses... Enquanto caminho, penso: é preciso que eu acabe de aprontar um aparelho que não descreva, mas, sim, inscreva, fotografe esses sons. Caso contrário, impossível organizá-los, montá-los. Eles fogem como foge o tempo. (VERTOV apud XAVIER, 1924, p. 260).

Essa noção da cidade como música advém do conceito de paisagem sonora de Murray Schafer compositor canadense que cunhou o termo "ecologia sonora". Paisagem sonora é a construção sonora de uma paisagem, mas que diferente de uma paisagem visual sua apreensão não pode ser feita de uma só vez. Para o entendimento de uma paisagem sonora é necessário vários registros e a criação de várias notações sonoras. A sonografia não é uma apreensão instantânea como a da fotografia. Assim como um mapa, a sonografia pode extrair informações da paisagem sonora, pois o microfone funciona como um close, como um 
microscópio. Em sua pesquisa The world soundscape project, Schafer confere à questão da poluição sonora e do ruído ambiental uma visão positivista. Sua proposta era a elaboração de um projeto acústico mundial que, através da conscientização a respeito dos sons existentes, pudesse prever o tipo de sonorização desejada para determinado ambiente.

Parece-me absolutamente essencial que comecemos a ouvir mais cuidadosa e criticamente a nova paisagem sonora do mundo moderno. Somente através da audição seremos capazes de solucionar o problema da poluição sonora. (SCHAFER, 1991. p. 13).

E sobre a cidade e a nova paisagem sonora Schafer analisa o ambiente acústico das máquinas:

\begin{abstract}
Os motores são os sons dominantes da paisagem sonora do mundo. Todos os motores compartilham um aspecto importante: são todos os sons de baixa informação, altamente redundantes. Isso quer dizer que, a despeito da intensidade de suas vozes, as mensagens que falam são repetitivas e em última análise, aborrecidas. (SCHAFER, 2012. p. 188).
\end{abstract}

Schafer vai criar duas designações, hi-fi e lo-fi, para descrever as diferentes paisagens sonoras. Na paisagem sonora hi-fi os sons se sobrepõem menos frequentemente, existe a noção de perspectiva do som, a diferença entre figura e fundo. Já na designação lo-fi os sinais acústicos são obscurecidos em uma população de sons superdensa, e é o que vivenciamos na vida urbana. A paisagem sonora lo-fi foi introduzida pela Revolução Industrial e ampliada pela Revolução Elétrica que se seguiu. A paisagem sonora lo-fi surge com o congestionamento do som produzido pela máquina. Para Schafer vivenciamos na cidade 0 que ele chama de linha contínua do som, sons que operam continuamente dia e noite provocados por máquinas como geradores e ar-condicionado um som contínuo e pesado de baixa frequência que podemos chamar de "rumor". Roland Barthes trabalha a ideia de rumor, que diferente do balbucio é o barulho da máquina que funciona bem e que tem um sentido musical.

\footnotetext{
Segue-se o paradoxo: o rumor denota um barulho limite, um barulho impossível, o barulho daquilo que, funcionando com perfeição, não tem barulho; rumorejar é fazer ouvir a própria evaporação do barulho: o tênue, o camuflado, o fremente são recebidos como sinais de uma anulação sonora. (BARTHES, 1982, p. 94).
}

A questão do ruído da cidade é experimentada no futurismo e é concebido como arte sonora, o itanumori de Russolo era um instrumento capaz de gerar múltiplos ruídos. Ruído entendido como um som que desorganiza outro, sinal que bloqueia o canal, ou desmancha a mensagem, ou desloca o código formado de feixes de defasagens arrítmicas e instáveis. Russolo propunha uma definição mais precisa do ruído: explicava que na Antiguidade só havia o silêncio, mas que, com a invenção da máquina no século XIX, nasceu o ruído: 
[...] ruído viera reinar soberano sobre a sensibilidade humana. Além disso, a evolução da música seguia de perto a multiplicação das máquinas, gerando uma competição de ruídos, não apenas na barulhenta atmosfera das grandes cidades, mas também no campo, que antes era normalmente silencioso, de modo que o som puro, na sua insignificância e monotonia, já não consegue despertar emoção. (RUSSOLO apud GOLDBERG, 2012, p. 26).

A arte dos ruídos de Russolo pretendia combinar o barulho dos automóveis, das explosões de motores, dos comboios e dos gritos das multidões. Construíram-se instrumentos especiais (os itanonumoris) que produziam esses efeitos ao girar uma manivela. Caixas de madeira retangulares que chegavam a ter um metro de altura, com amplificadores em forma de funil, continham vários motores que produziam uma família de ruídos: a orquestra futurista.

Para excitar nossa sensibilidade, a música se desenvolveu numa pesquisa complexa da polifonia e uma grande variedade de instrumentos tonais e cores. Eu tentei obter a mais complexa sucessão de acordes dissonantes preparando o terreno para a música do ruído. (RUSSOLO, 1967, p. 110).

Ao pensar a cidade e os ruídos por elas provocados um conceito também importante além da deriva é o détournement ${ }^{5}$ - desvio brusco, a obra interfere na cidade como na Graffiti Compostion de Christian Marclay, em que o artista espalha folhas em branco com grade pentatônica pela cidade, essas folhas sofrem interferências das mais variadas, a cidade interfere no trabalho constituindo partituras aleatórias que depois são executadas pelo artista, formando uma espécie de desvio, um alto grau de entropia da obra. As partituras foram transformadas pelas informações plásticas da cidade, como rabiscos, sujeira, chuva, lixo. Essas informações plásticas se transformaram em música, existindo de fato uma tradução do visual para o sonoro através dos desvios da cidade.

\section{Considerações finais}

Ao investigar produções artísticas em que relações entre sonoridade e visualidade aconteciam produzindo uma espécie de anteparo (partitura) entre elas, me deparei-me com produções muito diversas entre si. Como mapear produções que têm uma enorme diversidade material? Relações muito distanciadas, mas que mantêm uma tensão entre som e imagem. Possibilidades de recombinação entre o ver e o ouvir, relações que propõem dissoluções, novas cisões, e em que o ver é substituído pelo ouvir e vice-versa. O problema da formapartitura apareceu como um pano de fundo para muita das investigações, e realmente consolidou a via de mão dupla entre teoria e prática. Muitas vezes me via estimulada a

\footnotetext{
${ }^{5}$ Détournement foi uma técnica desenvolvida na década de 1950 pelo Letterist International, e mais tarde adaptado pela Internacional Situacionista a partir do filme Hurlements em faveur de Sade, em que, num dado momento, a imagem para e fica apenas o som causando uma instabilidade no espectador provocado por um desvio intencional.
} 
produzir "partituras" na forma de desenhos ou de vídeos em função das propostas artísticas com que entrava em contato. Ao problematizar essa relação tão fundamental no cinema, a relação ver/ouvir, me interessei por trabalhos em que essa relação se dava a partir de colisões, choques. Entrei em contato com a ideia de partitura num sentido expandido, como produzir trabalhos visuais e sonoros que tivessem a partitura como foco central. Como estabelecer metas de derivas a partir de um conceito de partitura expandida como a Naked City. Ao estabelecer parâmetros e programas para a criação artística procurava um sistema que tinha determinava todos os dias uma tarefa. O sistema me permitia a construção de uma narrativa pessoal que moldava o meu dia a dia. O sistema diário e cotidiano tornou-se um procedimento artístico.

\section{Referências}

BARTHES, Roland. O rumor da língua. In: O óbvio e obtuso. Rio de Janeiro: Nova Fronteira, 1982.

BENJAMIN, W. Imagens do pensamento, o caráter destrutivo. In: Rua de mão única. Obras escolhidas, vol II. São Paulo: Brasiliense, 1997.

BERNHARD, Thomas. O náufrago. 2 ed. São Paulo: Companhia das Letras, 2006.

BRECHT, George. Events. In: HENDRICKS, Jon (org.). O que é Fluxus e o que não é. Brasília: Centro Cultural Banco do Brasil; Detroit: Gilbert and Lila Silverman Fluxus Colletion Foundation, 2002.

CARNEIRO, Isabel Almeida. Naked City. In: Anais do 24ํㅡㄹ Encontro Nacional de Pesquisadores em Artes Plásticas. Santa Maria: ANPAP/PPGART/CAL/UFSM, 2015. ISSN: 2175-8212 [online]. Disponível em: http://anpap.org.br/anais/2015/simposios/s2/isabel_almeida_carneiro.pdf.

CERTEAU, Michel de. A invenção do cotidiano. Petrópolis: Vozes, 2012.

DAVILA, Thierry. Marcher, créer. Paris: Éditions du Regard, 2002.

DEBORD, Guy. Rapport sur la construction des situations. Paris: Mille et une nuits, 2000.

DELEUZE, Gilles; GUATTARI, Félix. Personagem conceitual. In: O que é a filosofia? São Paulo: Ed. 34, 1992.

JACQUES, Paola Berenstein. Apologia da deriva: escritos situacionistas sobre a cidade. Rio de Janeiro: Casa da Palavra, 2003.

ROÇA, Luciana Santos; TRAMONTANO, Marcelo. Polifonias, dissonâncias e ritmos: ouvir para construir cidades. V!rus, São Carlos, n. 9 [online], 2013. Disponível em: http://www.nomads.usp.br/virus/virus09/?sec=6\&item=1\&lang=pt. Acesso em: 18 mai. 2015.

LISSOVSKY, Maurício. A memória e as condições poéticas do acontecimento. In: GONDAR, Jô; DODEBEI, Vera. O que é memória social? Rio de Janeiro: Contracapa, 2005.

MACIUNAS, George. O que é Fluxus e o que não é. In: HENDRICKS, Jon (org.). O que é Fluxus e o que não é. Brasília: Centro Cultural Banco do Brasil; Detroit: Gilbert and Lila Silverman Fluxus Colletion Foundation, 2002.

MERLEAU-PONTY. O olho e o espírito. São Paulo: Cosac Naify, 2004.

RODRIGUES, Claudiney; CHAVES, Renan Paiva. O pensamento sonoro-visual de Walter Ruttman e a música de "Berlim: Sinfonia de uma metrópole" (1927). Doc On-line, n. 12, ago. 2012, p. 22-58. Disponível em http://www.doc.ubi.pt/12/dt_claudiney_carrasco.pdf. Acessado em: 20 maio 2015. 
ROLNIK, Suely. Cartografia sentimental: transformações contemporâneas do desejo. Porto Alegre: Sulina; Editora da UFRGS, 2011.

RUSSOLO, Luigi. The art of noise: (Futurist Manifesto, 1913). [L'arte dei rumori, trad. Robert Filiou.] New York: Something Else Press, 1967.

SCHAFER, Murray. O ouvido pensante. São Paulo: UNESP, 1991.

SCHAFER, Murray. A afinação do mundo. Editora UNESP: São Paulo, 2012.

TIBERGHIEN, Gilles. Imaginário cartográfico na arte contemporânea: sonhar o mapa nos dias de hoje. Revista do Instituto de Estudos Brasileiros, n. 57. São Paulo, dez. 2013, p. 233-252, p. 20. Disponível em: https://www.scielo.br/scielo.php?script=sci_arttext\&pid=S0020-38742013000200010.

TIBERGHIEN, Gilles. Hodológico. Revista-Valise, Porto Alegre, v. 2., n. 3, jul. 2012. Disponível em: https://seer.ufrgs.br/RevistaValise/article/view/30563/18969.

WATTS, Robert. No Event, 1964. In: HENDRICKS, Jon (org.). O que é Fluxus e o que não é. Brasília: Centro Cultural Banco do Brasil; Detroit: Gilbert and Lila Silverman Fluxus Colletion Foundation, 2002. 